\title{
Piggyback Jurisdiction in the Proposed Federal Criminal Code
}

The federal criminal law is currently a chaotic collection of statutes enacted piecemeal over the past two centuries. Although there have been several attempts at codification, the result in each case has been little more than a rearrangement of the existing provisions. ${ }^{1}$ In recognition of the continuing need for revision, Congress in 1966 created the National Commission on Reform of Federal Criminal Laws, with a broad mandate to revise and recodify the current statutes.? The Com. mission took its task seriously; in January 1971 it submitted the final draft of a proposed Federal Criminal Code which, if enacted, would constitute a major reform. ${ }^{3}$

The proposed Code departs significantly from present law in its treatment of federal jurisdiction. The Code simplifies and makes consistent existing jurisdictional provisions, and in addition includes a provision for "piggyback" jurisdiction, ${ }^{*}$ which would permit federal prosecution of a broad range of common crimes, normally punishable only by the states, when committed in association with federal offenses. The Commission justifies the piggyback provision as a rational and convenient solution to certain drafting problems inherent in a federal code. ${ }^{5}$ Critics, on the other hand, claim that it constitutes an unwarranted expansion of federal authority into the state domain. ${ }^{\circ}$ This

1. There have been three such recodifications: the Revised Statutes of 1873-74. Act of June 20, 1874, ch. 333, 18 Stat. 113; the Penal Code of 1909, Act of March 4, 1909, ch. 321, 35 Stat. 1088; and the revision of 1948, Act of June 25, 1948, ch. 645, 62 Stat. 683 (codified at 18 U.S.C. (1970)). For a survey of the history of the federal criminal law, see McClellan, Codification, Reform, and Revision: The Challenge of a Mlodern Federal Criminal Code, 1971 Duke L.J. 663 (1971). Senator McClcllan is Chairman of the Subcommittee on Criminal Laws and Procedures of the Senate Committee on the Judiciary, and was a member of the National Commission on Reform of the Federal Criminal Lavis. His article is based on a speech he gave before the Senate introducing the Commission's proposed Federal Criminal Code, 117 Coxc. Rec. S. 2955-3006 (daily ed., Mfar. 11, I971). 2. Act of Nov. 8, 1966, Pub. L. No. 89.801, 80 Stat. 1516, as amended, Act of July 8 , 1969, Pub. L. No. 91-39, 83 Stat. 44.

3. Final Report of the National Commission on Reform of Federal Camanal Lavis (1971) [hereinafter cited as FINAL REPORT]. The FINAL REIORT is reprinted in Hearings on Reform of the Federal Criminal Law's Before the Subcomm. on Criminal Lau's and Procedures of the Senate Comm. on the Judiciary, 92d Cong., Ist Sess., pt. 1 (1971) [hereinafter cited as Hearings]. The FINAL REPORT includes the full text of the Commission's proposed Federal Criminal Code [hereinafter cited as CODE]. An earlier draft of the Code is presented in National Commission on Reform of Feneral Cajainal Laws, Studi Draft of a New Federal Crusinal Code (19\%0) [hereinafter cited as Study Draft].

4. CODE $\$ 201(\mathrm{~b})$.

5. See Miclellan, supra note 1 , at 696.98 .

6. Younger, State v. Uncle Sam, 58 A.B.A.J. 155 (1972); Liebmann, Chartering a National Police Force, 56 A.B.A.J. 1070 (1970); National Association of Attorncys Ceneral. Disapproval of Study Draft of Proposed New Federal Criminal Code, printed in Hearings 6-11. 
Note will explore the functions of the piggyback provision, its constitutionality, and its implications for the scope and exercise of federal prosecutorial power.

I. The Proposed Code's Approach to Jurisdiction

\section{A. The General Jurisdictional Framework}

Unlike the states, the federal government does not have plenary criminal jurisdiction. Rather, it is limited to regulating criminal behavior that is in some way related to one of the constitutionally delegated federal powers. ${ }^{7}$ Federal criminal statutes have traditionally taken account of this limitation by including the requisite jurisdictional factors within the definition of each offense. The Lindbergh Law, for example, does not reach kidnapping per se, but instead makes transportation of a kidnapped victim in interstate commerce a federal offense. $^{8}$

This traditional approach raises several problems. First, it has occasionally led courts to treat jurisdictional factors as elements of the substantive offense. Under the mail fraud statute, for example, it has been held that an offender can be sentenced separately for each item mailed, regardless of the severity of the underlying fraud..$^{0}$ Similarly, courts have occasionally held that the government must prove that the defendant was aware of the particular jurisdictional factor that made the offense federal..$^{10}$

More significantly, the present approach has led to substantial inconsistencies in the definitions, penalties, and jurisdictional bases for sub. stantive offenses. For example, there now exist at least eleven different federal assault statutes, each associated with a different jurisdictional base. ${ }^{11}$ Some of these statutes define only one form of assault, ${ }^{12}$ while others prescribe up to five different degrees of that offense. ${ }^{13}$ The maximum punishment imposed by these statutes varies from one ${ }^{14}$ to

7. See p. 1216 infra.

8. 18 U.S.C. \$ $1201(1970)$.

9. Badders v. United States, 240 U.S. 391 (1916); Milan v. United States, 322 F.2d 101 (5th Cir. 1963), cert. denied, 377 U.S. 911 (1964).

10. It has been held, for example, that conviction under 18 U.S.C. $\$ 111(1970)$ for assaulting a federal officer requires proof that the defendant knew the viction was a federal officer, United States v. Bell, 219 F. Supp. 260 (E.D.N.Y. 1963), though most courts scem to have taken the contrary view, see Burke v. United States, 400 F.2d 866 (5th Cir. 1968), cert. denied, 395 U.S. 919 (1969).

11. 18 U.S.C. $\S \S 111,112,113,1153,1501,1655,1751,2113,2114,2116$, and 2191 (1970).

12. Id. $\$ 2113$ (d) (assault in the course of committing a bank robbery).

13. Id. $\$ 113$ (assault within maritime and territorial jurisdiction).

14. Id. $\S 1501$ (assault on a process server). 
twenty-five years. ${ }^{15}$ Assault on a mail clerk may violate up to three different statutes, ${ }^{16}$ but assaulting a cabinet officer is not a federal offense at all. ${ }^{17}$ Furthermore, when taken as a whole, the existing federal assault statutes protect a substantially broader class of potential victims than do the federal murder statutes. ${ }^{18}$ Many of these anomalies could obviously be eliminated by carefully redrafting the existing provisions, while still maintaining the traditional practice of defining jurisdictional bases together with substantive elements of federal offenses. Yet the opportunity for haphazard development through piecemeal legislation would remain, and new anomalies would undoubtedly develop. ${ }^{19}$

The authors of the proposed Code responded to this difficulty by taking a different approach to jurisdiction, separating the definitions of criminal conduct from the definitions of the circumstances that give rise to federal jurisdiction. Common crimes such as murder, theft, and arson are defined only once, as in a state code, and the definition of each offense is followed by a separate provision outlining the bases for federal jurisdiction over that offense. Furthermore, the most frequently invoked jurisdictional bases are set forth in a separate section at the beginning of the Code, $\S 201,20$ and are simply incorporated by reference

15. Id. $\S 2113(\mathrm{~d})$, see note 12 supra.

16. Id. $\$ \S 111,2114$, and 2116.

17. Conspiracy to assault a cabinet member, however, would be covered by 18 U.S.C. $\S 372(1970)$.

18. See Comment on Homicide, 2 Workixg Parers of the Nationst Comassios on Reforar of Federal Criminal Laws 823, 832 (1970) [hereinafter cited as Wonkive laing]. For a discussion of other oddities in the existing law, sec Schwartx, Federal Criminal Jurisdiction and Prosecutors Discretion. 13 LAW \& CoNTEMr. Prob. 64, 77-80 (1948): Abrams, Consultant's Report on Jurisdiction, I Working Parers 33, 40-42.

19. See Abrams, supra note 18 , at 40 .

20. Section 201 reads, in full, as follows:

$\$ 201$. Common Jurisdictional Bases.

Federal jurisdiction to penalize an offense under this Code exists under the circumstances which are set forth as the jurisdictional base or bases for that offense.

Bases commonly used in this Code are as follows:

(a) the offense is committed within the special maritime and territorial jurisdiction of the United States as defined in section 210;

(b) the offense is committed in the course of committing or in inmediate flight from the commission of any other offense defined in this Code over which federal jurisdiction exists;

(c) the victim is a federal public servant engaged in the performance of his official duties or is the President of the United States, the President-elect, the Vice President, or, if there is no Vice President, the officer next in the order of sucecssion to the office of President of the United States, the Vice President-elect or any individual who is acting as President under the Constitution and laws of the United States, a candidate for President or Vice President, or any member or memberdesignate of the President's cabinct, or a member of Congress, or a federal judge, or a head of a foreign nation or a foreign minister, ambassador or other public minister;

(d) the property which is the subject of the offense is owned by or in the cus. tody or control of the United States or is being manufactured, constructed or stored for the United States;

(e) the United States mails or a facility in interstate or foreign commerce is used in the commission or consummation of the offense; 
in the various substantive provisions to which they are applicable. For example, the Code contains only two assault offenses-simple and aggravated. ${ }^{21}$ A separate paragraph following each definition provides that federal jurisdiction exists over these offenses under four of the common jurisdictional bases, including $\S 201$ (a) ("the offense is committed within the special maritime and territorial jurisdiction of the United States ...") and $\S 201$ (c) ("the victim is a federal public servant engaged in the performance of his official duties ..."). ${ }^{22}$

This technique effectively cures the anomalies noted above. Since common crimes are defined only once, inconsistencies in definitions and penalties are eliminated. Similarly, disparities in the jurisdictional breadth of various substantive offenses, such as presently exist with respect to murder and assault, have generally been removed by assigning them identical jurisdictional bases. ${ }^{23}$ Furthermore, the bases themselves have been defined with a degree of generality that eliminates such anomalies as the lack of protection for cabinet members. ${ }^{24}$ Finally, the clear distinction between the definition of substantive offenses and the provision for jurisdictional bases insures that the latter will not become confused with the elements of the offense, thereby avoiding the distortions engendered by the current method of drafting. ${ }^{25}$

Though of considerable importance, these changes do not entail a radical shift in the treatment of federal criminal jurisdiction. Each substantive offense is still tied to a limited number of specific juris-

(f) the offense is against a transportation, communication, or power facility of interstate or foreign commerce or against a United States mail facility;

(g) the offense affects interstate or foreign commerce;

(h) movement of any person across a state or United States boundary occurs in the commission or consummation of the offense;

(i) the property which is the subject of the offense is moving in interstate or foreign commerce or constitutes or is part of an interstate or foreign shipment;

(i) the property which is the subject of the offense is moved across a state or United States boundary in the commission or consummation of the offense;

(k) the property which is the subject of the offense is owned by or in the cus. tody of a national credit institution;

(1) the offense is committed under circumstances amounting to piracy, as pre. scribed in section 212.

When no base is specified for an offense, federal jurisdiction exists if the offense is committed anywhere within the United States, or within the special maritime and territorial jurisdiction of the United States.

21. CODE $\$ \S 1611,1612$.

22. Cone $\$ \$ 1611(3), 1612(2)$.

23. This is not to say that inconsistencies in jurisdiction have been entirely ellininated from the proposed Code. Sometimes the Commission has refused to let the rationalizing process overcome allegiance to the jurisdictional contours of the present law. For cxample, the Code provides for jurisdiction over kidnapping, but not murder, when "movement of any person across a state or United States boundary occurs in the commission or consum. mation of the offense" (CODE $\$ 201(\mathrm{~h})$ ). CODE $\$ \$ 1634,1609$.

24. See CoDE $\$ 201(\mathrm{c})$, quoted note 20 supra.

25. To avoid such judicial distortions, the Code specifically provides that culpability need not be proven with regard to jurisdictional factors. ConE $\$ \$ 204,302(3)$ (c). 
dictional bases. Furthermore, most of these bases are similar to those presently employed. ${ }^{26}$ For the most part, any expansion of federal jurisdiction created by the Code derives from the process of generalizing the jurisdictional bases and reducing their number in order to avoid the gaps and inconsistencies in the old approach.."7

Insofar as the Code's approach does expand federal jurisdiction, it reflects the Commission's view that controlling the exercise of prosecutorial discretion is often a better method of restricting federnl power than the traditional approach of limiting jurisdiction. This view is reflected in $\$ 207,28$ a novel provision that describes the circumstances under which federal authorities may refrain from prosecuting when there is concurrent federal and state jurisdiction.."

26. In this respect, the FiNAL REIORT is somewhat more restrained than the carlier Study DRAFT, which occasionally provided jurisdictional bases for offenses to which they

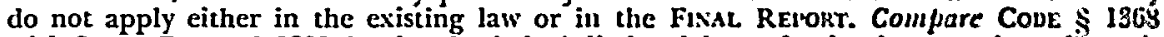
with STUDY DRAFr \$ 1368 (setting forth jurisdictional bases for local corruption offenses).

27. It is difficult to judge precisely how much of an expansion in juriscliction is actu. ally involved. In some cases it appears to be considerable. For example, in place of the particularistic theft offenses in the existing law the Code contains a series of general theft provisions, CODE $\$ \S 1731-1734$, for which jurisdiction is provided inder all but two of the common jurisdictional bascs, CODE $\$ \$ 201(c)$ and $201(1)$, see note 20 supra. (Jurisdiction over theft offenses is defined in CoDE $\$ 1740)$. One factor that complicates any judg. ment as to the breadth of federal jurisdiction under the Code is that the scope of sev. eral of the broader jurisdictional bases, such as Cove $\$ \$$ 201(c) and 201(g), will depend in large part on the manner in which they are interpreted.

28. Section 207 reads, in full, as follows:

$\$ 207$. Discretionary Restraint in Exercise of Concurrent Jurisdiction.

Notwithstanding the existence of concurrent jurisdiction, federal law enforcentut agencies are authorized to decline or discontinue federal enforcenent efforts whenever the offense can effectively be prosecuted by nonfederal agencies and it appears that there is no substantial federal interest in further prosecution or that the offense primarily affects state, local or foreign interests. A substantial federal interest exists in the following circumstances, among others:

(a) the offense is serious and state or local law enforcement is impeded by interstate aspects of the case; (b) federal enforcement is believed to be necexary to vindicate federally protected civil rights; (c) if federal jurisdiction exists under section 201(b), the offense is closely related to the underlying offense as to which there is a substantial federal interest; (d) an offense apparently limited in its impact is believed to be associated with organized criminal activities extending beyond state lines; (e) state or local law enforcement has been so corrupted as to undermine its effectiveness substantially.

Where federal law enforcement efforts are discontinued in deference to state, local or foreign prosecution, federal agencies are directed to cooperate with statc, local or foreign agencies, by providing them with evidence already gathered or othervise, to the extent that this is practicable without prejudice to federal law enforcement. The Attorney General is athorized to promulgate additional guidelines for the exercise of discretion in employing federal criminal jurisdiction. The presence or absence of a federal interest and any other question relating to the exercise of the discretion referred to in this section are for the prosecuting authoritics alone and are not litigable.

Section 207 and its implications for federal enforcement are discussed at pp. 1232-3j infra.

29. In its general approach to the problem of jurisdiction-including the separation of jurisdictional matters from the definition of offenses, the provision for broader and more consistent jurisdiction over common crimes, and the establishment of explicit policy restraints on the use of prosecutorial discretion-the Cole follows the suggestions made in Schwartz, Federal Criminal Jurisdiction and Prosecutors' Discretion, 13 Lnw \& CoN- 


\section{B. Piggyback Jurisdiction}

The piggyback provision of the Code, however, provides a new though not unprecedented ${ }^{30}$ area of federal jurisdiction. The provision would create federal jurisdiction over offenses committed "in the course of committing or in immediate flight from the commission of any other offense defined in [the] Code over which federal jurisdiction exists." 31 The crimes which could thus be piggybacked onto other Code offenses (the latter termed "underlying" offenses) consist primarily of common crimes against persons, such as homicide, assault, kidnapping, and rape (set out in Chapter 16 of the Code), and common crimes against property, such as arson, burglary, robbery, and theft (set out in Chapter 17). Thus, if an escaping federal prisoner were to kill someone during the course of his escape, the piggyback provision would permit federal prosecution for the homicide as well as for the escape. ${ }^{32}$

As the Commission notes, there is substantial precedent for piggyback jurisdiction. The Federal Bank Robbery Act, enacted in 1934, provides for an additional sentence when the offender assaults, kidnaps, or kills someone "in committing" a bank robbery. ${ }^{33}$ Similarly, a num. ber of federal offenses, including the major civil rights offenses ${ }^{34}$ and several crimes involving destruction of facilities used in interstate commerce, ${ }^{3 \overline{5}}$ carry aggravated penalties "if death results" or "if personal injury results." Even stronger precedent for the piggyback provision, though not mentioned by the Commission, is $\S 7$ of the Enforcement Act of $1870 .{ }^{36}$ That section, codified as R.S. $5509,{ }^{37}$ authorized aggra-

TEMP. PROB. 64 (1948). Professor Schwartz was the Staff Director for the Commission that prepared the Code. His article is still the most thoughtful treatment of the sub. ject of federal criminal jurisdiction. See also Allen, Kenison, Willens \& Schwarti, Role of the Federal, State and Local Governments in the Administration of Criminal Justice: $A$ Panel, 1961 Rel'., A.B.A. SECrion of CriminsL LAw 30; Abrams, Consultant's Report on Jurisdiction, 1 Wokking PApers 33. None of these discussions, however, considers anything like the Commission's proposed piggyback provision.

30. See pp. 1214-16 infra.

31. CODE $\S 201(b)$.

32. The applicable provisions would be CODE $\$ \$ 1601$ (Inurder) and 1306 (cscapc).

33. 18 U.S.C. $\$ \S 2113(\mathrm{~d})$, (c) (1970).

34. Id. $\$ \S 241,242,245(\mathrm{~b})$.

35. Id. $\S \S 34,844(\mathrm{i})$, 1992. See also id. $\S \S 844$ (d) (interstate transport of cxplosives), 844(f) (destruction of federal facilities). Other piggyback-type statutes provide for a sepit. rate sentence of from one to ten years for cmploying a firearm, id. $\$ 924(c)$, or cxplosives, id. $\$ 844(\mathrm{~h})$, in the commission of any federal felony.

36. An Act to enforce the Right of Citizens of the United States to vote in the scveral States of this Union and for other Purposes, May 31, 1870, ch. 114, 16 Stat, 140.

37. Rev. Stat. $\$ 5509$, Act of June 20, 1874, ch. 333, 18 Stat. 113 (2d ed. 1878, atuthorizcd by Act of March 2, 1877, ch. 82, 19 Stat. 268, as amended, Act of March 9, 1878, ch، 26, 20 Stat. 27). 
vation of sentences according to the penalties provided by state law when a state crime was committed "in the act of violating" either of two civil rights statutes. ${ }^{38}$ The experience with R.S. 5509, ${ }^{30}$ which was

38. Section 5 of the Enforcement Act (subsequently coditied as R.S. 5507) made it a misdemeanor to hinder any individual in the exercise of the right of stiffrage guaranteed by the Fifteenth Amendment. Section 6 (R.S. 5508), now codified as 18 U.S.C. $\$ 241$ (1970), made it a felony, punishable by up to ten years in prison, to conspire to interfere with any citizen in the free exercise of any right or privilege securcd to him by the Constitution or laws of the United States. Section 7 (R.S. 5509 ) then effectively pigs. backed the criminal law of each state onto the two preceding sections:

If in the act of violating any provision in either of the two preceding sections any other felony or misdemeanor be committed, the offender shall be punished for the

same with such punishment as is attached to stuch felony or misdemeanor by the

laws of the State in which the offense is committed.

Rev. Stat. $\$ 5509$, note $\mathbf{3 7}$ supra.

The legislative history of R.S. 5509 is rather sparse. R.S. 5507,5508 , and 5509 were intro. duced together in the Senate as amendments to the Enforcement Act. Their sponsor, Senator Pool, said little about R.S. 5509 other than that it would lend extra force to the other two provisions and that it was particularly necessary because local enforcement would often be inadequate for the offenses it would cover. CoNG. GLous, 1Ist Cong., 2d Sess. 3612-13 (1870). (Senator Pool's remarks are also reproduced in an appendix to the Supreme Court's opinion in United States v. Price, 383 U.S. 787, 816 (1966).) Although the Enforcement Act as a whole was assailed at length by southern legislators as a usurpation of state jurisdiction, there was little explicit criticism of R.S. 5509 itself. But see CoNG. Grobe, 41 st Cong., 2d Sess. 3804,3873 (1870).

R.S. 5509 differs from the piggyback provisions contained in the Code, in that it pigg)backed state penalties onto federal crimes rather than utilizing federally-defined offenses for this purpose. Moreover, it piggybacked all such crimes rather than a specified calcgor: of them, although the proposed Code in fact permits pigsybacking for most of the major crimes covered by state law. The available set of underlying offenses was much narrower, however, encompassing only R.S. 5507 and 5508, rather than the entire federal code. From the reported cases it appears that R.S. 5509 was in fact used only in conjunction with R.S. 5508 , apparently because the constitutionality of R.S. 5507 was thrown in considerable doubt soon after its passage by the Supreme Court's decision in United States v. Recse, 92 U.S. 214 (1875), which struck down other similar provisions from the same act. Later decisions explicitly declared R.S. 5507 itself invalid. James v. Bowman, 190 U.S. 127 (1903); Lackey v. United States, 107 F. 114 (6th Cir.), cert. denied, 181 U.S. 621 (1901).

These distinctions notwithstanding, the operative principles of the pigg back provision and R.S. 5509 are quite similar. If anything, the function of sentence grading, advanced by the Commission as a justification for piggybacking, see note 93 infra, is even more explicit in the older statute, since by its terms it simply aggravated the penalty for the underlying federal offense rather than permitting separate federal punishment for the state offense. Although the language of R.S. 5509 did not compel that interpretation, it was the view taken by the courts, at least when the issue was confronted direelly. See Davis v. United States, 107 F. 753 (6th Cir. 1901), discussed at p. 1217 infra. The clfect would be much the same no matter which interpretation were used, sinee the elements of the state offense would have to be proven in any case. Cf. Motes $v$. United States, 178 U.S. $458(1900)$.

The similarity of the two provisions is further emphasized by the fact that RS. 550S, one of the two underlying offenses for R.S. 5509, is one of the civil rights offenses that the authors of the Code have singled out as being particularly appropriate for the application of piggybacking. See note 93 infra.

39. During the forty years that it was in force R.S. 5509 was employed not only in prosecuting for serious misconduct interfering with the rights of blacks, Rakes v. United States, 212 U.S. 55 (1909); Riggins v. United States, 199 US. 517 (1905); United States v. Cruikshank, 92 U.S. 542 (1875); United States v. Avery, 80 U.S. 251 (1872); United States v. Powell, 151 F. 648 (C.C.N.D. Ala. 1907), aff'd per curiam, 212 U.S. 504 (1909); but also in prosecuting for the murder or attempted murder of federal witnesses, informants, and law enforcement officers, United States v. Mason, 213 U.S. 115 (1909); Motes v. United States, 178 U.S. 458 (1900); In re Quarles, 158 U.S. 532 (1895); United States V. Sanges, 144 U.S. 310 (1892); Davis v. United States, 107 F. 753 (6th Cir. 1901); United States v. Patrick, 54 F. 338 (C.C.M.D. Tenn. 1893). The reason for these federal prosecutions was evidently that adequate local enforcement was not forthcoming, presumably beeause in 
later repealed, ${ }^{40}$ led the Attorney General to recommend in 1890 that it be

so broadened as to make any felony committed while in the act of violating any statute of the United States triable in the United States courts, and punishable according to the law of the state wherein the same is committed. ${ }^{41}$

\author{
The Code's piggyback provision comes close to meeting that recom- \\ mendation.
}

\title{
II. The Constitutionality of Piggybacking
}

Congress can create federal offenses only when their punishment is "necessary and proper" to the execution of constitutionally delegated powers. ${ }^{42}$ The administration of criminal justice is otherwise reserved to the states under the Tenth Amendment. ${ }^{43}$

all but one of these cases, United States v. Mason, supra, the defendants werc involved in evasion of the federal liquor tax, an activity that was probably not unpopular at the local level. Cf. Davis v. United States, 103 F. 457 (C.C.W.D. Tenn. 1900), aff'd, 107 1F. 753 (6th Cir. 1901), where the court specifically noted that, "to its shame," the state had never prosecuted for the offense, which involved the murder of a deptity United States marshal who was attempting to arrest the defendant for illegal distilling. $103 \mathrm{~F}$. at 472 .

Such conduct was evidently prosecuted under R.S. 5508 and 5509 because it was not covered adequately by other provisions in the existing federal law. The provision thit specifically covered interference with federal witnesses carricd a maximum sentence of six years, Rev. Stat. $\$ 5406$ (2d ed. 1878), a penalty that undoubtedly secmed inadecuate for murder. See United States v. Sanges, 48 F. 78 (C.C.N.D. Ga. 1891), appeal dismisscd 114 U.S. 310 (1892), where, in upholding a demurrer to an indictment under R.S. 5508 atid 5509 for murdering a witness, the court noted that the only effect of its decision was to force the government to prosecute under R.S. 5406 instead. $48 \mathrm{~F}$. at 83 . It scems that tit the time there was no statute at all that directly outlawed the murder of federal officers. See United States v. Davis, 103 F. 457, 472 (C.C.W.D. Tenn. 1900), aff'd, 107 F. 759 (6th Cir. 1901). Of course, such prosecutions called for a broad interpretation of R.S. 5508 , which the courts provided in all cases except Sanges, supra.

In light of this history, it is noteworthy that the authors of the piggyback provisian in the proposed Code justify it in part as a means of providing further protection for federal witnesses and informants. See note 93 infra.

40. R.S. 5509 was repealed when the federal criminal law was recodificd in 1909 , $A \mathrm{ct}$ of March 4, 1909, ch. 321, 35 Stat. 1153, largely as a concession to southern legislaturs who viewed it as an unpleasant remnant of Reconstruction. This and other argunents in favor of repeal can be found at 42 Cosc. REC. 591, 616-22, 6-19, 2235, 2387.90 (1908).

41. 1890 ATTY GEN. ANN. REP. Xiii, xiv.

42. For present purposes, the most useful interpretation of the necessary and proper clause is that given in United States v. Darby, 312 U.S. 100 (19.11). That case involved a federal criminal statute enacted under the commerce power, but the Court noted the parallel with the exercise of other powers as well:

Congress, [in legislating under the commerce clause], may choose the means reason. ably adapted to the attainment of the permitted end, even though they involve con. trol of intrastate activities. Such legislation has often been sustained with respect to powers, other than the commerce power granted to the national government, when the means chosen, although not themselves within the granted power, were nevertheless deemed appropriate aids to the accomplishment of some purpose within an admitted power of the national government.

312 U.S. at 121.

43. Screws v. United States, 325 U.S. 91, 109 (1915); United States v. Fox, 95 U.S. 670 (1877); United States v. Cruikshank, 92 U.S. 542 (1875). As the Court noted in United States v. Darby, 312 U.S. 100 (1941), the Tenth Amendment adds no further limitation 
Although the cases upholding the constitutionality of R.S. $5509^{44}$ and the "incidental crimes" provisions of the Federal Bank Robbery Act ${ }^{45}$ strongly suggest the validity of piggyback jurisdiction, they provide little doctrinal guidance.

R.S. 5509 was upheld on the theory that it did not provide federal jurisdiction over distinct offenses, but simply permitted aggravation of the underlying civil rights conspiracy offense. ${ }^{40}$ It was held that Congress, having the authority to punish the conspiracy, "was competent to take notice of such incidents of violence and wrong as were likely to happen in the prosecution of such combinations," and to adjust the punishment accordingly. ${ }^{47}$ This rationale, however, is of limited utility in analyzing the piggyback provision. First, it relies on the distinction between punishment of a separate offense and aggravation of the underlying offense, ${ }^{48}$ which piggybacking eliminates by explicitly joining separate offenses. Second, the cases upholding R.S. 5509 fail to explicate the required-relationship between the "incidents of violence" and the underlying federal offense.

The decisions under the Bank Robbery Act, although affirming jurisdiction over such remotely related offenses as the subsequent murder of an accomplice to prevent his becoming an informer, ${ }^{40}$ have gone

to the scope of federal power, but rather "states but a truism that all is retained which has not been surrendered." 312 U.S. at 124.

The text focuses on the scope of delegated powers, but an attack on the pigg back: provision might also be grounded in substantive due process. The standard to be applied then would presumably be whether there was a rational connection between punishment for a piggybacked crime and the protection of any legitimate federal interest. Such $a$ rational connection test has continuing vitality in the review of federal criminal statutes at least where statutory presumptions are concerned. Cf. Leary v. United States, 395 U.S. 6 (1969); Tot v. United States, 319 U.S. 463 (1943); Ashford \& Risinger, Presumptions, Assumptions, and Due Process in Criminal Cases: A Theoretical Otervieu, 79 I'1LE L.J. 165 (1969). The latter issue, however, is substantially a procedural question. In consider. ing the substantive limits on Congress power to punish it seems that the due process approach is now disfavored, and that courts will limit themselves to dealing with such issues from the point of view of the scope of delegated powers. Cf. United States $v$. Perez, 402 U.S. 146 (1971). The fundamental issue, in either case, would be much the samewhether prosecution for piggybacked offenses is reasonably related to the effectuation of a federal interest.

44. Rakes v. United States, 212 U.S. 55 (1909); Davis v. United States, 107 F. 753 (6th Cir. 1901); See also Motes v. United States, 178 U.S. 458 (1900). Sec pp. $1214-16$ supra.

45. Clark v. United States, 184 F.2d 952 (10th Cir. 1950), cert. denied, 340 US. 95J (1951); Gilmore v. United States, 124 F.2d 537 (10th Cir. 1942), cerl. denied, 316 U.S. 601 (1942).

46. As discussed in note 38 supra, R.S. 5509 was employed exclusively in conjunction with R.S. 5508, the conspiracy statute, and consequently the cases deal with it only in that context.

47. Rakes v. United States, 212 U.S. 55, 57-58 (1909), quoting from Davis v. United States, 107 F. 753, 755 (6th Cir. 1901).

48. A concern with this seemingly insignificant distinction can also be found in the congressional debate on the repeal of R.S. 5509.42 CoNG. REC 618 (1908).

49. United States v. Etheridge, 424 F.2d 951 (6th Cir. 1970), cerl. denied, 400 US. 993 (1971). The Bank Robbery Act extends jurisdiction to murders committed "in avoid. ing or attempting to avoid apprehension" for the commission of the robbery, 18 U.S.C. $\$ 2113(\mathrm{e})(1970)$, and thus clearly covers the circumstances in Elheridge; it would of course 
no further in defining the required relationship among the offenses than to state that

[t]ime and place is not the constitutional test, but the relation of the offense to the robbery. ${ }^{50}$

These cases do, however, suggest the general principle that federal jurisdiction can extend to an entire criminal transaction ${ }^{n 1}$ once jurisdiction exists over any part of it, regardless of the number of distinct offenses involved.52 This formulation in turn suggests two possible constitutional justifications for piggybacking, each of which involves the notion of a criminal transaction. The first is based on substantive federal interests extending to the entire range of the defendant's acts, the second on procedural considerations focusing on the efficiency and fairness of a single trial.

\section{A. The Substantive Aspect of "Transaction": Means-Ends Relation- ships}

Full effectuation of the federal interest in regulating conduct clearly within the scope of delegated powers would seem to require jurisdic-

require some straining to bring that offense within the narrower language of the piggyback provision in the proposed Code. The difference in the language of the two pro. visions, however, does not detract from the significance of the holding in Elheridge, which is that federal power can constitutionally extend to even such a remotely related crime. Under the proposed Code, the Etheridge situation could be handled more dircetly as a charge of murder piggybacked onto a charge of tampering with an informant, Cove: $\$ 1322$.

50. Clark v. United States, 184 F.2d 952, 954 (10th Cir. 1950), cert. dénied, 340 U.S. $955(1951)$.

51. The term "transaction" is employed here simply becatuse it has been used previ. ously to denote a similar concept in other, related areas of the federal criminal law. Rule 8 (a) of the Federal Rules of Criminal procedure provides for joinder of offenses arising from the "same transaction." Federal statutes have grantcd immunity from sub. sequent prosecution for any "transaction" as to which an individual has been compelled to give testimony in a federal proceeding. See Act of Attg. 20, 1954, ch. 769, 68 Stat. 745 (repealed 1970); UlImann v. United States, 350 U.S. 422 (1956). And it has been arglicd, and occasionally held, that a "same transaction" test should be applied to determine the scope of the double jeopardy rule. See Ashe v. Swenson, 397 U.S. 436, 453.57 (1970) (Brennan, J., concurring); J. Sigler, Double Jeopdrdy 67 (1969); Kirchheimer, Thc Act, The Offense, and Double Jeopardy, 58 YALE L.J. 513 (1949). The Code uses the term "criminal episode" in its provisions covering multiple prosecutions to convey a similax notion. See pp. 1235 -36 infra.

52. The Code's definition of the crime of robbery lends further support to the notion that the piggyback provision is intended to apply to a single criminal transaction. Section 1721 provides that a person is guilty of robbery if he commits an assault "in the course of committing" a theft, thereby using the piggyback language to reflect the traditional notion that a single transaction encompassing both theft and assault constitutes a distluct offense. The Code's use of the phrase "in the course of committing" is not novel. "I'he same words are found in the definitions of robbery and burglary in the Modd l'cual Code. In fact, the Model Penal Code gocs so far as to provide that

$A$ person is guilty of robbery if, in the course of committing a theft, he [assitults someone, or] commits or threatens immediately to commit any felony of the first or second degree.

Model Penal Code $\$ 222.1$ (Proposed Final Draft, 1962) (cmphasis added). S'ct also ill. $\$ 221.1$ (defining burglary). 
tion over other conduct when one of the acts is a means of committing the other. ${ }^{53}$ Piggybacked offenses will generally satisfy this criterion.

Most common will be those cases in which the piggybacked offense is committed as a means of accomplishing the underlying offense. For example, murder may be the means by which a person is deprived of his civil rights or prevented from appearing as a witness in a federnl trial. Kidnapping a teller may be a means of assuring the success of a bank robbery. ${ }^{\overline{4}}$

The rationale for imposing an additional penalty when criminal means are used to secure a federally-forbidden end is clear. An offender who is willing to employ such means will generally represent a more serious threat to the federal interest which is at stake-for example, the electoral process or federally insured bank deposits-than one who is not, and consequently a higher sentence will be appropriate for the sake of deterrence, rehabilitation, and isolation of the offender from society..$^{55}$

This means-end approach receives strong support from the recent decision in Perez $v$. United States, ${ }^{, 50}$ which sustained a particularly farreaching application of its logic. In that case, the Supreme Court held that Congress could outlaw loansharking, a class of crime which is essentially local in character, since it had been found that this crime was a common means ${ }^{57}$ of financing interstate organized crime, an activity clearly within the reach of federal power. ${ }^{58}$

53. The same idea can be expressed using the traditional criminal law concept of intent. That is, full protection of the federal interest in a particular act requires jurisdiction over other acts committed with the intent to commit the prohibited act.

54. A number of existing federal criminal statutes focus explicitly on a means-end relationship. For example, the Hobbs Act, which outlaws any robbery that "affects com. merce," defines robbery as theft committed "by means of" violence or the threat of violence. 18 U.S.C. $\S 1951$ (1970). Similarly, it is a federal offense 10 assault a postal employee "with intent to" steal the mail. I8 U.S.C. \$211. (1970). See note 53 supra.

55. See Note, $A$ Rationale of the Law of Aggratated Theft, 5t Colus. L.R. 84, 102 (1954).

The means-end analysis applies as well to crimes committed "in immediate flight from" another offense. To take an extreme example, a bank robber might kill a pedestrian while driving recklessly away from the scene of the crime, and consequently be guilty of negligent homicide. Even in such a case, it could well be argued that driving recklessly wizs a means by which the robber sought to elude his pursuers and thus bring the underlying offense to a successful completion, and that this extra measure of violence made him a more serious offender. Or, put more directly, the government has an interest in cap. turing persons who violate its laws, and thus has an interest in punishing a person who commits an offense in order to avoid such capture.

56. 402 U.S. 146 (1971).

57. The holding in Perez goes well bejond the piggyback approach in that it does not require a showing that the particular offense involved is a means of promoting other federally proscribed activity, but only that the means-end relationship holds for the class of offenses taken as a whole. 402 U.S. at $154-57$. Clearly, many crimes that would satisfy the Perez means-end approach could not be said to have been committed "in the course of committing" a federal offense, as required by the pigg) back provision.

58. The Supreme Court's decision in Screws v. United States, 325 U.S. 91 (194J), reflects a similar analysis, expressed in terms of intent, see note 53 supra. There it was 
It may also happen that the underlying offense is the means by which the piggybacked offense is committed. For example, an offender might place a bomb aboard a commercial airliner ${ }^{50}$ as a means of committing murder, or impersonate a federal officer in order to commit fraud. In such cases, federal authority to prosecute for the piggybacked offensc can also be justified as necessary to provide full protection for federal interests. Thus, impersonation of a federal official is a federal offense because, when used to commit another offense, it tends to discredit federal credentials. The degree of this damage is best measured by the magnitude of the related offense, ${ }^{60}$ and thus the federal interest is best vindicated by prosecuting both offenses together. Similarly, Congress has the authority to outlaw the destruction of commercial aircraft bccause it deters the free use of interstate transportation facilities. $A$ murder connected with such destruction obviously aggravates the interference with the use of those facilities. This reasoning receives support from the long line of cases under the commerce clause, including those sustaining the Lottery Act, ${ }^{61}$ the Mann Act, ${ }^{62}$ the National Motor Vehicle Theft Act, ${ }^{63}$ and the Lindbergh Law, ${ }^{64}$ which have established the principle that Congress' authority over interstate commerce carries with it the authority to punish the criminal ends for which such commerce is used. ${ }^{\circ 5}$

\section{B. The Procedural Aspect of "Transaction": Pendent Jurisdiction}

An alternative constitutional justification for piggybacking derives from procedural rather than substantive considerations, along lines analogous to the doctrine of pendent jurisdiction in civil litigation. As developed by the Supreme Court in Uniled Mine Workers $\%$. Gibbs, ${ }^{60}$ that doctrine permits federal courts to try state claims together

held that, while punishment of murder is generally a matter which is reserved to the states, it can become a proper subject for federal sanction when committed with a spccific intent to deprive an individual of his civil rights.

59. Destruction of a commercial airliner could be prosecuted directly under Cove $\$ 1702$ (endangering by fire or cxplosion), using as a jurisdictional basc Cove $\$ 201$ ( $\$$ (the offense is against an interstate transportation facility).

60. See United States v. Barnow, 239 U.S. 74 (1915).

61. Champion v. Ames, 188 U.S. 321 (1903).

62. Hoke v. United States, 227 U.S. 308 (1913).

63. Brooks v. United States, 267 U.S. 432 (1925).

64. Seadlund v. United States, 97 F.2d 742 (7th Cir. 1938).

65. Further precedent for this substantive interest approach can be found in the federal statutes permitting defendants to remove state prosecutions to federal courts when stib. stantial federal interests are involved, 28 U.S.C. \$ 1442(a) (1970) (removal of criminat cases against officers of the United States); id. $\$ 1442 a$ (removal of criminal cases against members of the armed forces); id. $\$ 1443$ (removal of criminal cases interfering with fedcrally-protected civil rights). The constitutionality of such statutes is well established, Tennessee v. Davis, 100 U.S. 257 (1879).

66. 383 U.S. 715 (1966). 
with federal claims when they "derive from a common nucleus of operative fact" and "if, considered without regard to their federal or state character, ... [the plaintiff] would ordinarily be expected to try them all in one judicial proceeding ...." theory that claims that are closely related comprise but one constitutional "case." 68 Its justification lies "in considerations of judicial economy, convenience and fairness to litigants."

Pendent jurisdiction has apparently never been explicitly extended to criminal cases. Nonetheless, much the same rationale would seem to apply. Article III "cases" clearly include criminal prosecutions. 0 Furthermore, as Justice Brennan, the author of the Gibbs opinion, has noted, " $[t]$ he considerations of justice, economy, and convenience that have propelled the movement for consolidation of civil cases apply with even greater force in the criminal context," particularly in light of the traditional principle that a defendant should not be subjected to multiple trials for the same act. ${ }^{71}$ In addition to avoiding the expense and injustice of multiple prosecutions, a single trial would minimize the loss of liberty imposed by pre-trial detention and avoid inconsistent sentencing and treatment decisions. ${ }^{72}$

Piggyback jurisdiction, however, goes beyond the notion of pendent jurisdiction generally applied in civil litigation, in that the appended offense is a federal crime, governed by federal law, rather than simply a state offense tried at the same time. ${ }^{73}$ It might be argued that the proposed piggyback jurisdiction thus exceeds the constitutional limits on congressional authority indicated in Erie R.R. $v$. Tomphins. ${ }^{\text {is }}$ In his opinion for the Court in that case, Justice Brandeis stated, in a con-

67. Id. at 725 .

68. Id.

69. Id. at 726 .

70. Tennessee v. Davis, 100 U.S. 257, 264, 268 (1879).

71. Ashe v. Swenson, 397 U.S. 436, 456 (1970) (Brennan, J., concurring). Ashe itself involved only a determination of the scope to be afforded the double jeopardy rule as applied to repeated state prosecutions. Howerer, Justice Brennan explicitly noted the parallel between that issue and the rule of pendent jurisdiction cnunciated in Gibbs. Id. at 454,456 .

Although the double jeopardy clause has been held inapplicable to dual state and federal prosecutions, see note 141 infra, the Code contains statutory prohibitions against

such re-prosecutions, see pp. $1235-37$ infra.
72 . One particularly unfortunate result of dual state and federal prosecutions is the detainer system, under which a federal prisoner is generally denied parole if the state notifies federal authorities that it intends to prosecute after the prisoner has served his federal sentence. See Schwartz, supra note 18, at 71.

73. In this respect R.S. 5509, pp. 1214-16 supra, is closer to the concept of pendent jurisdiction applied in civil litigation than is the Code's pigg'back provision.

Similarly, in those criminal prosecutions remored to federal court, 28 U.S.C. $\$ \$ 1442(a)$. $1442 a, 1449$ (1970), see note 65 supra, state, rather than federal, substantive law is applied in the federal trial. See Tennessee v. Davis, 100 U.S. 257 (1879); FED. R. Crus. P., Adrisory Committee Note to Rule $54(\mathrm{~b})(1)$.

74. 304 U.S. 64 (1938). 
troversial passage, ${ }^{7 \overline{5}}$ that Congress could not constitutionally prescribe rules of substantive law to be applied in diversity cases. ${ }^{70}$ That principle might be said to extend to any case where a matter normally within the exclusive jurisdiction of the states is tried in federal court solely for purposes of procedural convenience. ${ }^{77}$

Whatever the status of Erie's constitutional doctrine with respect to diversity law, it need not be considered controlling as to piggyback jurisdiction in criminal cases. First, unlike diversity cases, federal prosecutions involving piggybacked offenses will always include an underlying offense that will be tried according to federal law. To apply state law to a piggybacked offense at the same trial would be cumbersome and confusing, requiring the jury to apply two different and possibly conflicting standards to the same conduct. ${ }^{78}$ Second, in the vast majority of cases, federal jurisdiction over the piggybacked offense itself will also be justifiable in terms of a substantive means-cnds analysis as described above, and in those cases the power to apply federal law is clear. There will, of course, be some cases in which a procedural justification alone exists for piggybacking. ${ }^{70}$ But disallowing the application of federal law in those few cases would lead to a complex, time-consuming dispute as to whether a case came within the exception, and thus might undercut congressional efforts to apply federal law to protect federal interests. Finally, the problem of forum-shopping, while not entirely absent, ${ }^{80}$ is far less significant with respect to

75. The constitutional discussion in Erie has been the subject of extensive commen. tary. References are collected in C. Wright, Federal CoukTs 230-31 (1970).

76. 304 U.S. at 78. Of course, the Erie doctrine raises no question as to the power of Congress to prescribe procedural rules for criminal cases in federal court, regardless of the basis for federal jurisdiction.

77. State law is generally applied to pendent claims in civil suits, Note, Problems of Parallel State and Federal Remedies, 71 HARv. L. REv. 513 (1958), and it has bec1l stiggested that, following Erie, this result may be constitutionally required, Comment, $P$ ('il. dent Jurisdiction-Application of the Erie Doctrine, 24 U. CH1. L. REv, 543, 552 (1957), It is by no means clear, however, that the Erie rule extends this far, D'Oench, Duhme \& Co. v. FDIC, 315 U.S. 447, 465 (1942) (Jackson, J., concurring), and, at least when the pendent claim involves issues of unfair competition, there is some authority for the application of federal law. Bulova Watch Co. v. Stolzburg, 69 F. Supp. 543 (D. Mass. 1947); Zlinkoff, Erie v. Tompkins: In Relation to the Law of Trade-Marks and Unfair Competition, 42 Colum. L. Rev. 955 (1942); Note, 60 Harv. L. Rev. 821 (1947). Cf. Taussig v. Wellington Fund, Inc., 187 F. Supp. 179 (D. Del. 1970).

78. The same argument has been made with respect to pendent civil claims, Zlinkoff, supra note 77, at 988-90; Note, 60 HARv. L. REv. 821 (1947), although, as indicated it note 77 supra, the general practice has been to apply state law.

79. Arguably such a case would arise if an offender were to set off several boinbs at the same time in several different buildings, one of which was a federal courthousc whille the others had no connection with the federal government. It might be difficult to argite that the bombing of the federal building stood in a means-end relation to the other bombings, yet a single trial for the whole episode would clearly be proccdurally cont. venient.

80. In strict terms, of course, the type of forum shopping available in diversity cases is impossible in criminal prosecutions, since both state and federal prosecutors are limited to using the courts established by their respective governments. Nonetheless, it seculs 
piggybacking in criminal cases than it is in diversity cases, where it provides substantial justification for the application of state law. Put briefly, the application of federal law to piggybacked offenses is "necessary and proper"si to the exercise of federal power to try the entirety of an Article III "case."s2

The appropriate scope of a single "transaction" from the procedural perspective has not been carefully defined. Gibbs speaks of " $\mathrm{a}$ common nucleus of operative fact," 83 but it is not clear how much of a factual overlap is required. ${ }^{4}$ The interests of convenience and judicial cconomy supporting the procedural argument suggest that federal authority should extend to all offenses which, were they prosecuted by one authority, could be joined in a single trial. Modern rules of joinder, sucl as Rule 8(a) of the Federal Rules of Criminal Procedure, ${ }^{85}$ though not definitive explications of the constitutional limits, are useful guidelines since they were written with precisely those interests in mind and have already been subject to judicial interpretation. ${ }^{80}$ Indeed the Court in Gibbs referred to the liberal joinder provisions in the Federal Rules

plausible that, in cases of concurrent jurisdiction, cither a state or federal prosecutor might defer to, or even encourage, prosecution in the other forum because of lariations in the law to be applied-for example, because the available penalty in the prosectutor's own jurisdiction seems either too lenient or 100 harsh. Howerer, if appropriate restraints on the exercise of prosecutorial discretion are implemented, as discussed at pp. 1232-34 infra, the choice of a federal or state court should seldom if ever be made simply because the law to be applied will be less favorable to the defendant.

81. Cf. Hanna v. Plumer, 380 U.S. 460, $471-72$ (1965); Ely, Legislative and Administra. tive Motivation in Constitutional Lau, 79 YALE L.J. 1205, 130J-06 nn. 300, 301 (1970).

82. The application of federal law to piggybacked offenses might also be challenged as a violation of the equal protection element in Fifth Amendment duc process, IBolling v. Sharpe, 347 U.S. 497 (1954), when federal substantive law is harsher than state lawfor example, if the death penalty is retained, despite the Commission's contrary recom. mendation, CODE Chapter 36, Introductory Comment, and the dubious constitutional status of such punishment after the Supreme Court's recent decision in Furman v: Georgia, 40 U.S.L.W. 4923 (U.S. June 29, 1972). This claim vould probably fail under the traditional equal protection test, Kotch v. Board of River l'ort Pilot Comm'rs, 330 U.S. $552,556(1947)$, because the federal government cannot be said to have made an arbitrary classification of offenders-Congress has chosen to subject to federal law only those already accused of having committed federal crimes. However, at least when the defendant's life is at stake, the courts are likely to apply the "fundamental interest" analysis which requires a compelling state interest to uphold the classification. Cf. Harper v. Virginia Bd. of Elections, 383 US. 663, 670 (1960); Skinner v. Oklahoms, 316 U.S. 535. 541 (1942). In those cases in which there is a substantive federal interest in prosecuting for the piggybacked offense, it seems probable that courts would find a compelling state interest. An equal protection challenge could, however, raise much more substantial difficulties in those few cases in which the only justification for federal prosecution of the piggybacked offense is procedural, see note 79 supra.

83. 383 U.S. 715, 725 (1966).

84. See Note, UMW v. Gibbs and Pendent Jurisdiclion, 81 HaRs. L. REs. 657, 659.62 (1968).

85. Rule 8(a) of the Fcderal Rules of Criminal Procedure provides that two or more offenses may be joined if they "are of the same or similar character or are based on the same act or transaction or on two or more acts or transactions connected together or constituting parts of a common schene or plan."

86. Cf. I C. Wright, Feneral Practice ANd Procedoure \$ 143 (1969); Ashe v. Sicnson, 397 U.S. 436,454 n.8 (1970) (Brennan, J., concurring). 
of Civil Procedure, analogous to those in the Criminal Rules, as a clear expression of the philosophy underlying its opinion. ${ }^{87}$ At the same time, the defendant's interest in avoiding multiple prosecution argucs for including within a single transaction all offenses for which subsequent prosecution by the same authority would be barred by the double jeopardy clause. The latter standard has, however, generally been more narrowly construed than the joinder standard. ${ }^{88}$ Since a broader standard would fully protect the defendant's interest in avoiding multiple prosecutions, and convenience and economy are constitutionally cognizable interests, the joinder definition of a single transaction would seem the proper rule.

The foregoing discussion indicates that most conceivable applications of piggyback jurisdiction would be constitutional under either a substantive or procedural theory of federal jurisdiction. Yet some crimes, though committed close enough in time or place to a federal offense to come arguably within the language of the piggyback pro. vision, might not meet either of the transaction tests-that is, either be part of a criminal transaction affecting a federal interest or have factual questions in common with the federal offense. This situation is particularly likely to occur in connection with crimes that continue over an extended period of time, such as possession offenses, conspiracies, and illegal businesses like gambling. ${ }^{80} \mathrm{~A}$ teenager in possession of marijuana, for example, might engage in shoplifting. Under the Code, he would be subject to federal prosecution for possession of a dangerous or abusable drug. ${ }^{00}$ Federal prosecution might then be possible for the shoplifting offense as well, since it was arguably committed "in the course of committing" the drug offense. Yet it would be difficult to argue that either offense was a means of committing the other, and probably the only common factual element would be the defendant's identity. ${ }^{91}$ Federal prosecution of a piggybacked offense in such a casc

87. 383 U.S. 715,724 (1966).

88. It seems that no uniform test regarding the scope of the double jcopardy rule has yet developed. Various courts have applied "same evidence," "same offense," and "sante act" tests, as well as the seemingly broader "same transaction" test. See J. Siclkk, Douutle JEOPARDY 63-69 (1969); Ashe v. Swenson, 397 U.S. 436, 450.58 (1970) (Brennan, J., con1• curring).

89. See p. 1228 infra.

90. CODE $\$ 1824$.

91. There may be cases not far removed from this example in which the federal inter. est is more plausible. For example, suppose that a man were caught robbing a local stolc while in possession of heroin. It could well be that the robbery was simply a means by which the offender supported his habit, or, differently stated, that it wis done with intent to use the proceeds to procure more heroin. Certainly the relationship between the two offenses would appear to be as close as that which the Court relicd upon in Perez, discussed at p. 1219 supra. On the other hand, one might still be hesitiut to 
might, therefore, excced constitutional bounds. $A$ court faced with this situation could construe the piggyback provision to avoid the constitutional question by incorporating the appropriatc substantive and procedural definitions of a criminal transaction. ${ }^{92}$

\section{The Scope of Piggyback Jurisdiction}

As the preceding discussion indicates, the basic rationale for piggyback jurisdiction is to insure federal jurisdiction over the entirety of a criminal transaction when jurisdiction extends to any part of it.93 Whenever an offense stands in a means-end relation to or has factual elements in common with an offense as to which there is an interest in federal prosecution, there will necessarily be a federal interest in prosecuting the former offense as well. Piggyback jurisdiction is thus essentially a procedural device giving federal authorities the power to prosecute an entire criminal transaction when federal prosecution is

construe the language of the piggyback provision to cover such a situation. See note 49 supra and p. 1231 infra.

Of course, if the heroin that the offender had in his possession was the thing stolen, there would be no question about the appropriateness of a pigg backel robbery charge.

92. Some support for such an interpretation can be found in the Commission's commentary on the piggyback provision, which notes that " In the course of committing ... requires more than a mere temporal connection between the two offenses." Cone $\$ 201$, Comment.

93. The Commission justifies piggyback jurisdiction primarily as a means of dealing with the problem of "grading," that is, of designing the Code so that the sentencing structure is appropriately coordinated with the severity of the offense involied-a problem that has proved particularly troublesome under present law. See Code $\$ 201$, Cotnment; McClellan, supra note 1, at 696-97. For example, impersonation of a lederal official is presently a felony punishable by up to three years imprisomment, 18 US.C. $\$ 912$ (1970), "treatment too severe for mere impersonation of a marshal in order to serve legal process, but not severe enough for a kidnapping" or major Iraud which inight be commiticd by impersonating a federal official." CODE $\$ 201$, Comment. The Coule reduces the impersonation offense to a misdemcanor, CODE $\$ 1381$, and relics on the pigg) back provision to insure appropriate punishment for the related offensc.

The Commission notes that piggyback jurisdiction should prove particularly useful in prosecuting civil rights offenses and crimes against federal witnesses and informants. Ske Brown \& Schwartz, New Federal Criminal Code is Submilled; 56 .1.B.1.J. 814, 847 (1970) (an article by the Commission's Chairman and Staff Director introducing the proposed Code). Thus, 18 U.S.C. $\$ 242$ (1970) (deprivation of rights under color of laws) now provides for a maximum sentence of onc year in all cases except "if death results," in which case life imprisonment can be imposed. See p. 1214 supra and pp. 123940 in/ra. Under the Code, the basic offense remains a misdemeanor with a maximum penalty of one year, CoDE $\$ 1502$, but can be accompanied by a pigghacked charge for the conduct causing the deprivation-whether murder, assault, arson, or kidnapping. Similarly, interfering with a federal witness or informant is presently punishable by a maximum sentence of five years, even if the means of interference is murder, 18 U.S.C. \$\$ 1503, 1510 (1970), but under the Code can lead to a higher range of sentences when piggs backed offenses are involved.

The description of piggyback jurisdiction as a "grading" device tends to foctus attchtion on the problem of determining the appropriate sentence for a given course of con. duct, rather than on the antecedent issue of deternining what elcmenis of the defendant's conduct are to be federally punished-that is, the jurisdictional question. It is the latter, more fundamental issue which is the primary focus of the present discussion. 
warranted at all. ${ }^{94}$ The scope of piggyback jurisdiction is therefore dependent not only on the range of offenses that may be piggybacked, but also on the breadth of the underlying federal jurisdiction. It should be noted that piggybacking would not extend federal jurisdiction to persons not otherwise subject to federal prosecution. ${ }^{0}$ While the pro. vision extends federal authority to certain acts presently beyond its reach, the primary determinant of the scope of federal jurisdictionand the most appropriate focus for federalist concerns-is still the jurisdiction provided for underlying offenses.

Given that the purpose of the piggyback provision is to encompass all elements of a criminal transaction for which federal prosecution is appropriate, it would seem that any offense should be eligible for piggybacking onto any other federal offense. There should be no arbitrary limits on the prosecutor's ability to charge for the entirety of the transaction. Such an approach would be consistent with the basic philosophy, underlying the Code's other jurisdictional reforms, of defining federal jurisdiction broadly enough to include all major classes of cases for which federal enforcement might be justified, and relying on control of prosecutorial discretion to prevent inappropriate uses of that power. .06

94. The question of when federal prosecution is warranted is, of course, exceedingly complex. Common justifications for federal enforcement are that the offense affects the operations of the national government, that state althorities are unable to prosccute effec. tively because of interstate complications or resource limitations, or that state atuthorities will not prosecute in good faith because of local corruption or racial prejudice. For further discussion of these issues, sce Schwartz, supra note 18; Abrams, stupra note 18. Of course, in determining the appropriate scope to be afforded any justification for federal enforcement, it is necessary to consider the countervailing intcrests gencrally favoring state law enforcement: the increased potential for diversity and experimentation in handling problems of criminal justice, see Duncan v. Louisiana, 391 U.S. 145, 171.93 (1968) (Harlail, J., dissenting), and protection from the dangers of centralized authority, set $\mathbf{R}$. JAckson, THe Sulreme CourT in THE AMerican System of Government 70.71 (1955). 'The Cioll. mission has tried to come to grips with these issues directly in $\$ 207$, which contaitis guidelines for the exercise of prosecutorial discretion. See note 28 supra and pp. 1232. 34 infra. Extended analysis of these issues is not necessary for present purposes since the transaction rationale for piggybacking will apply whatever justifications for federal pros. ccution are employed.

95. There appear to be only two possible exceptions. First, there could be a case in which an individual was an accomplice to a piggybacked offense but not to the underly. ing offense. For example, an individual might assist a bank robber in stealing a car to secure the robber's escape, yet not be aware of the bank robbery itself, and hence would be an accomplice to a crime committed "in immediate flight from" the robbery, but not to the robbery. Such cases will obviously be rarc.

Second, it might be argued that the piggyback provision would cover a crime committed by a bystander or victim of a federal crimc. To take a somewhat strained example, a debtor might unjustifiably assault an agent of his creditor who impcrsonates a federal marshal in serving legal process. Yet, while prosecution for the assault might require proof of some of the same facts as the impersonation offense itsclf, it scems an inappro. priate-and ungrammatical-interpretation of the piggyback provision to say that the assault was "committed in the course of committing" the impersonation.

96. See p. 1213 supra and pp. 1232-34 infra. 
The Commission's original Study Draft ${ }^{27}$ did in fact provide piggyback jurisdiction for nearly all offenses to which it could be applied. The Final Report, ${ }^{98}$ however, restricts piggyback jurisdiction by limiting both the offenses that employ the piggyback provision as a jurisdictional base and the offenses available as underlying offenses. Given the inconsistency of any such limitations with both the logic of piggybacking and the Commission's general jurisdictional approach, the Final Report's changes call for careful examination.

\section{A. Limitations on Piggybacked Offenses}

As noted earlier, ${ }^{99}$ the Final Report limits piggyback jurisdiction to those common crimes against persons and property contained in Chapters 16 and 17 of the Code. The only exception is the extension of the piggyback base to four other offenses concerning corruption and intimidation of local officials. ${ }^{100}$ In terms of the Code as a whole, this is not a major jurisdictional restriction; most of the other chapters of the Code contain offenses, such as those involving national security, government operations, internal revenue, and civil rights, as to which federal jurisdiction is plenary.

One other chapter, however, contains offenses that are not normally within the federal jurisdiction. This is Chapter 18, entitled "Offenses Against Public Order, Health, Safety, and Sensibilities," which covers riot, trafficking in firearms, gambling, obscenity, and drug offenses. In the Study Draft, piggyback jurisdiction was provided for the more serious of these offenses, including inciting riot, ${ }^{101}$ supplying or receiving illicit firearms, ${ }^{102}$ gambling in violation of local law, ${ }^{103}$ and promoting prostitution. ${ }^{10+}$ In the Final Report, on the other hand, none of the Chapter 18 offenses were given piggyback jurisdiction.

There are two possible justifications for this restriction. First, it is unlikely that such offenses would often be so closely related to an underlying offense as to form part of the same transaction. Clearly, however, there could well be situations in which piggyback jurisdiction over these offenses would be useful and justifiable. For example, a local

97. See note 3 supra.

98. See note 3 supra.

99. See p. 1214 supra.

100. CODE $\$ \$ 1361$ (Bribery), 1362 (Unlawful Rewarding of Public Servants), 1366 (Threatening Public Servants), and 1367 (Retaliation).

101. STUDY DRAFT (and CoDE) $\$ 1801$.

102. Id. $\$ \S 1811,1812,1813$. The definitions of these offenses in the Code differ somewhat from those in the Study Draft. See note 119 infra.

103. Id. $\$ 1831$.

104. Id. $\$ 1841$. 
gambling operation could be maintained in close connection with an illicit drug business, or an individual could incite a riot in the course of destroying government property or interfering with interstate trans. portation facilities. Since the gambling operation might be the means of financing the drug business, or a nucleus of facts common to both the riot and property destruction offenses might exist, there could well be a federal interest in prosecuting the entire transaction that would be frustrated by denying piggyback jurisdiction to Chapter 18 offenses.

Second, piggyback jurisdiction may have been withdrawn out of concern that the on-going nature of several Chapter 18 offenses might result in inappropriate applications of piggybacking. There is, of course, opportunity for abuse. An individual who operates an illegal gambling business might, at some time during the protracted period of its operation, commit another unrelated federal crime and then be charged in federal court with a piggybacked gambling offense as well, since it could arguably be said to have been committed "in the course of committing" the federal offense. Yet this eventuality, which also presents itself as a consequence of possession offenses, ${ }^{105}$ can be resolved by judicial interpretation of the piggyback provision ${ }^{106}$ and controls on prosecutorial discretion. It seems unnecessary, and inconsistent with the Code's general outlook, to contract jurisdiction in response to this danger.

\section{B. Limitations on Underlying Offenses}

Similar conclusions follow from an examination of the proposed limitations on underlying offenses. In the Study Draft, piggybacked offenses could have been prosecuted when associated with "any other offense over which federal jurisdiction exists," 107 rather than "any other offense defined in this Code over which federal jurisdiction ex. ists," as provided in the Final Report. ${ }^{108}$ The change is significant. There are a large number of federal offenses, most of them regulatory, defined not in the Criminal Code but in other titles of the United States Code. Typical are provisions prohibiting unfair trade practices, safety equipment violations, and improper labeling of food and drugs. ${ }^{109}$ The elimination of such regulatory offenses as underlying

105. See p. 1224 supra.

106. See p. 1225 supra.

107. STUDY DRAFT $\$ 201(b)$.

108. CoDE $\$ 201(\mathrm{~b})$ (emphasis added).

109. A table of current regulatory statutes with criminal penalties is included as an appendix to Schwartz \& Markowitz, Comment on Regulatory Offenses, I Working PuI'Es 403, 410-17. 
offenses for piggybacking is another reflection of the generally more restrictive approach to jurisdiction taken in the Final Report. Again, however, the Study Draft's position seems more consistent with the rationale for piggyback jurisdiction and with the general reliance on limiting discretion rather than jurisdiction.

In the first place, the expansion of federal jurisdiction that would result from allowing common crimes to be piggybacked onto regulatory offenses would probably be slight. It is unlikely that many crimes of the type included in Chapters 16 and 17 could ever be said to have been committed "in the course of committing"-much less "in immediate flight from the commission of"-regulatory violations. On the other hand, there might be considerable justification for federal prosecution of those offenses that actually occur in connection with regulatory offenses such as piggybacked offenses closely related to violations of health and safety standards or fraudulent business practices provisions. Thus, a piggybacked charge of negligent homicide for the deaths resulting from the improper labeling of a dangerous drug ${ }^{110}$ or a piggybacked charge of theft for a violation of a consumer credit disclosure requirement ${ }^{111}$ might be justified, both because the regulations were designed to provide protection against precisely those consequences and because of the substantial overlap of factual proof required for both offenses.

The Final Report moves part way toward meeting this problem by including in Chapter 16 a special offense of "reckless endangerment" that prohibits creation of "a substantial risk of serious bodily injury or death to another."112 The offense carries a one year maximum sentence unless "the circumstances manifest . . . extreme indifference to the value of human life," in which case the maximum is seven years. ${ }^{113}$ A unique jurisdictional provision allows it to be piggybacked onto any other federal offense, whether or not contained in the Criminal Code. ${ }^{114}$ The reckless endangerment offense is particularly appropriate for piggybacking onto regulatory offenses designed to protect health and safety, and for this reason the special piggyback jurisdiction provided is clearly justified.

110. Under present law, such a regulatory violation could be punished by a maxinum sentence of three years, even if intent to mislead were shown. 21 U.S.C. \$ 333 (1970). CoDE \& 3006 would limit the maximum sentence for any offense outside the Code to one year. 111. 15 U.S.C. $\$ 1611$ (1970) provides for a maximum sentence of one jear for violation of provisions in the Truth in Lending Act, id. $\$ \$ 1601 \mathrm{el}$ seg.

112. CoDE $\$ 1613$. The provision essentially follows MODEL PENAL CODE $\$ 2112$ (Pro. posed Final Draft, 1962).

113. CODE $\$ 1613$.

114. The language used is the same as that employed in $\$ 201(b)$ as it appeared in the Study Draft. See p. 1228 supra. 
Yet it is not clear why only this offense, among all those listed in Chapters 16 and 17, should be amenable to piggybacking onto offenses outside the Code. As noted above, for example, a sufficiently serious violation of drug labeling regulations might warrant a negligent homicide charge as well. Moreover, it would seem that piggyback jurisdiction for such a charge might be obtained even as the Code is presently written, since nothing appears to prevent a prosecutor from piggybacking reckless endangerment onto the regulatory violation, and then piggybacking negligent homicide, or another appropriate offense, onto the charge of reckless endangerment. The Code contains no explicit bar to such double piggybacking and, as suggested above, it might be appropriate in certain circumstances. ${ }^{115}$

Admittedly, extension of piggyback jurisdiction to include regula. tory violations as underlying offenses would create some opportunity for abuse. The ongoing nature of some regulatory offenses-such as licensing or reporting violations-raises the possibility that other, unrelated criminal activity may occur during the extended course of that violation and thus arguably fall within the language of the piggyback provision. Again, however, legislative and judicial limitations on the use of discretion would seem an adequate safeguard, and would avoid an arbitrary limitation on prosecutorial power. ${ }^{110}$

Given the generally broad definition of piggyback jurisdiction and the Code's general reliance on prosecutorial discretion, it is difficult to discern a persuasive reason for the Final Report's retreat from the Study Draft's approach to piggybacking; perhaps the changes were undertaken simply to increase the political acceptability of the Code. ${ }^{117}$

115. It may be that the Commission did not intend to provide an opportunity for such double piggybacking. If so, and if the more restrictive language of the piggyback provision in the Final Report reflects a strong-and heretofore unarticulated-policy, contrary to that suggested in the text, against permitting crimes other than reckless endatiger. ment to be piggybacked onto regulatory offenses, then an explicit prohibition agalinst double piggybacking should be included either in the reckless endangerment provision or in the piggyback provision itself.

116. In this connection, it should be noted that an aggressive federal prosecutor might try piggybacking any of a host of common crimes onto the Code's tax cuasion provisions, ConE $\$ \$ 1401,1402$. If taken far enough, this approach could result in federal jurisdiction over virtually any crime which resulted in an unreported gain to the offender. (1indecel, it has been argued that practice under the existing statutes already approaches too close to this result. Cf. Rutkin v. United States, 343 U.S. 130 (1952) (Black, J., dissenting).) Such an application of piggybacking, however, while not beyond the range of a liberal inter. pretation of the means-end test proposed, pp. 1218.20 supra, would clearly require stretch. ing the meaning of the phrase "in the course of committing" unreasonably, and most likely would not survive judicial scrutiny.

117. The Study Draft provoked some harsh criticism. See Licbmann, sttpra notc 6; National Association of Attorneys General, supra note 6. 
A similar concern may explain the refusal, in both versions, to make certain crimes in the Code itself underlying offenses for purposes of piggybacking. Most notable are the three provisions that prohibit supplying or receiving firearms when the recipient intends to commit a crime with the firearm or is a member of a specially defined class of ineligible recipients, or when the firearm itself is of a particular character. ${ }^{118}$ Clearly, some offenses could be committed in connection with a firearms transaction and thus be appropriate subjects for piggybacking. For example, an offender might shoot a police officer attempting to prevent receipt of an interstate firearms shipment. Yet the extension of piggyback jurisdiction to these offenses would not lead to jurisdiction over all crimes subsequently committed with the firearm. Although receipt of the firearm may be the means of committing a subsequent robbery, the latter offense can hardly be said to have been "committed in the course of committing or in immediate flight from" the firearms purchase, within the ordinary meaning of those words. ${ }^{110}$ The inconsistency of the firearms exclusion with both the rationale of piggybacking and the Code's general jurisdictional approach is sharply revealed by the fact that the Commission permits piggybacking onto one of the same supplying and receiving offenses when explosives rather than firearms are involved. ${ }^{120}$

118. CoDE $\$ \S 1811,1812,1813$.

119. Thus here, as elsewhere, the ordinary meaning of the language of $\$ 201$ (b) proves narrower than the transaction tests proposed at pp. 1218-25 supra. See notes 49,91 , and 116 supra.

Note that the result here would be quite different if the Commission's recommendation for the outlawing of handguns were adopted, CoDE Comment preceding $\$ 1811$. If possession of a handgun were a federal crime, and if the offense were available as an underlying offense for piggybacking, then virtually all crimes committed with handguns would become federal offenses. Such a substantial expansion of federal juriscliction might not be necessary to effectuate the federal interest in gun control, and consequently there might be good reason for excluding such a possession offense as an underlying offense for purposes of piggybacking.

In the Study Draft, $\$ 1811$ extended to possessing as wcll as supplying and recciving firearms, and consequently there may have been more substantial justification for cxcluding this offense from the piggyback base there than in the Final Report.

120. CODE $\$ 1811$.

Both the Final Report and the Study Draft also exclude as an underlying offense the fugitive felon offense, CODE $\$ 1310$, which makes it a federal crime to cross a state line in order to avoid prosecution for a state felony, or to avoid giving cvidence in a state proceeding. The purpose of the statute is to permit federal authorities to apprehend a stispect and turn him over to state authorities for prosecution; it is virtually never used as a basis for federal indictment. In fact, the Commission's consultant on jurisdiction recommended that the fugitive felon offense be eliminated altogether in favor of a provision simply giving the federal government authority to arrest state offenders who have fled interstate. Abrams, Consultant's Report on a Fugitive Felon Offense, I W'onkinc Parens 551. Thus, the decision not to extend piggyback jurisdiction to this offense can be rationalized on the ground that, since the fugitive felon offense will never be prosecuted as a federal offense at all, neither the means-end argument nor the convenience of a single trial would justify piggyback jurisdiction. 
IV. Jurisdiction Versus Enforcement: The Exercise of Prosecutorial Discretion

The desirability of giving greater scope to piggyback jurisdiction than is provided by the Final Report is of course dependent to some degree on the effectiveness of the controls imposed on the exercise of prosecutorial discretion.

In the past, prosecutorial policy has been a matter internal to the Justice Department, largely free from public influence or scrutiny. ${ }^{121}$ The resulting pattern of enforcement has been, at best, uneven. In some cases, federal enforcement has almost entirely displaced state cnforcement, for no apparent reason. Federal authorities, for example, have assumed substantial responsibility for the investigation and pros. ecution of bank robbery ${ }^{122}$ and interstate automobile theft ${ }^{123}$ even though the federal interest in prosecuting for such activity appears relatively small.

On the other hand, there are examples of considerable restraint. For instance, the Hobbs Act grants federal jurisdiction over any robbery that "affects commerce," 124 and could easily be construed to cover rob. bery of almost any business. Nonetheless, prosecutions under the Act have been infrequent. ${ }^{125}$

Section 207 of the proposed Code, which sets forth guidelines for the exercise of prosecutorial restraint, represents an effort to introduce some rationality and consistency into enforcement policies. The section "authorizes" federal authorities to defer to state enforcement whenever the offense can be effectively prosecuted by local authorities and no substantial federal interest is involved. It describes a number of circumstances in which "a substantial federal interest" exists: where there are interstate impediments to effective state prosecution; where federal involvement is necessary to vindicate federal civil rights; where there is an association with interstate organized crime; and where there is corruption of local enforcement authorities. ${ }^{126}$ With respect to piggy-

121. An informative inside view of the exercise of prosecutorial discretion at the fed. eral level is presented in Kaplan, The Prosecutorial Discretion-A Comment, 60 Nw. U.L. REv. 174 (1965). Occasionally, Justice Department policy on the excrcise of prosccutorial discretion has come to light in the context of a lawsuit. See Redmond v. United States, 384 U.S. 264 (1966); Screws v. United States, 325 U.S. 91, 159.60 (1945).

122. 18 U.S.C. \$ 2113 (1970). State enforcement authoritics have accused the FBI of "hogging" bank robberies simply because they are big cases. Cf. Kaplan, supra note 1a1, at 192 .

123. 18 U.S.C. $\$ 2312(1970)$. As of 1970 , this was the most frequently prosecuted fed. eral offense. MicClellan, supra note 1, at 699.

124. 18 U.S.C. $\$ 1951$ (1970).

125. Stein, Comment on Robbery, 2 Working Papers 903, 910.

126. CoDE $\S 207$. 
backed offenses, it states that the necessary interest exists if "the offense is closely related to the underlying offense, as to which there is a substantial federal interest." 127

The effectiveness of Section 207, however, is subject to question. Its standards are so vague as to represent more an expression of attitude than a workable set of criteria. Furthermore, the provision is advisory; it merely "authorizes" federal prosecutors to decline prosecution in certain circumstances, and is expressly made non-litigable. In order to give the section more force, the Commission suggests, with what seems unreasonable optimism, that Congress might use it in appropriations hearings as a yardstick for assessing the employment of federal resources. ${ }^{128}$

Some effort might be made to strengthen the language of Section 207. For example, federal prosecutors could be "directed" rather than "authorized" to decline prosecution whenever the established criteria are not satisfied and the requirement that the piggybacked offense be "closely related" to the underlying offense could be replaced with a more explicit version of the transaction test outlined previously.129 The improvements that can be derived from such rephrasing are likely to be limited, however, both because of the difficulties at the legislative level of defining explicitly and comprehensively all of the factors relevant to the exercise of prosecutorial discretion, and because of the lack of sanctions for disregarding the criteria, however defined. ${ }^{130}$

The Commission's consultant on jurisdiction has surveyed a number of alternative methods of controlling the exercise of prosecutorial discretion. ${ }^{131}$ For example, to increase the specificity of the guidelines, the Attorney General could be required to issue public statements of prosecutorial policy or to promulgate appropriate administrative regulations. These approaches, however, would still"leave authority to define those policies solely in the hands of the Justice Department and would introduce only the control derived from public exposure, unless the rules were made subject to judicial review. To insure greater protection of state interests, various mechanisms for bringing state and local authorities into the decision-making process could be em-

127. Id. Section 207 is quoted in full at note 28 supra.

128. CoDE $\$ 20 \%$, Comment. See Abrams, supra notc 18, at 60 .

129. See pp. 1218-25 supra.

130. The criteria set forth in $\$ 207$ are cxamined in some detail in Dobbjn, $A$ Pro. posal for Changing the Jurisdictional Provisions of the New Federal Criminal Code, ji CoRnerl L. REv. 198 (1972), and an altered version is proposed. The proposal, however, can at best be considered a marginal improvement over the original.

131. Abrams, supra note 18, at 57-62. 
ployed. ${ }^{132}$ Thus, federal prosecutors could be required to consult with local authorities before making a decision, to defer prosecution for a set period to permit local prosecution, or to await a request from state authorities for federal action. ${ }^{133}$

As the consultant's report suggests, ${ }^{134}$ more explicit and detailed formulation and public disclosure of federal enforcement policy ap. pears desirable. Making matters of prosecutorial policy litigable or formally involving non-federal authorities in the decision-making process, however, would probably create more problems than such devices would solve. ${ }^{135}$ It appears that the better policy would be to defer judgment on such additional controls until there has been substantial experience with prosecutorial policy under the new Code.

Although direct state participation in federal decision-making may not be desirable, state capacity to prosecute for an entire transaction that involves a strictly federal crime, parallel to the federal power pro. vided by the piggyback provision, might be helpful in dealing with the problems of federalism inherent in concurrent jurisdiction. Section 201(b) insures that when a federal juror is assaulted, the federal government will be able to prosecute for both the intimidation of the juror and the assault. States, however, can generally prosecute only for the assault. ${ }^{136}$ If multiple prosecutions are to be avoided in such situations, the federal prosecutor will have to choose between, on the one hand, prosecuting the entire transaction in federal court simply to insure that the defendant will be charged for the uniquely federal offense, even though the state is perfectly capable of prosecuting for the piggybacked offense, or, on the other hand, leaving the case to state authorities and dropping the federal offense. The better solution, it would seem, would be to give the state courts jurisdiction over the federal offense, so that it could be prosecuted by state authorities along with

132. The discussion here has focused primarily on whether federal or state authorities should handle particular cases. Yet concurrent jurisdiction also gives rise to the possibility of conflicting state and federal policies as to whether certain types of crime are to be prosecuted at all, and the nature and number of offenses with which given classes of offenders who are being prosecuted are to be charged. Some mechanism for collaboration, whether formal or infornal, seems particularly appropriate to harmonize such policies.

133. See also Dobbyn, supra note 130, in which it is proposed that federal prosectitors be required to obtain approval from a federal magistrate before prosecuting for common crimes.

134. Abrams, supra note 18 , at 58 .

135. For example, if requests from local authorities were required, there would have to be some mechanism whereby federal authorities could ignore that requirement in cases involving a bad faith refusal to prosecute at the state level due to local corruption or racial prejudice. And making prosecutorial policy litigable would obviously lead to sub. stantial delays in criminal cases. For further difficulties see Abrams, supra note 18, at 59-62.

136. Intimidation of a juror, federal as well as state, may occasionally be a violation of state law. See Model Penal Code $\$ 240.2$ (Proposed Official Draft, 1962). 
the state offense. Section 3231 of Title 18 presently grants federal district courts exclusive jurisdiction over federal crimes. ${ }^{137}$ That provision could be modified to give state courts jurisdiction either over all federal offenses, or, paralleling the piggyback provision, only over those federal offenses committed in the course of committing state offenses. There is precedent for giving the states jurisdiction over federal offenses, ${ }^{138}$ and the constitutionality of such action seems clear. ${ }^{130}$ Appropriate safeguards could be devised to prevent abuse. ${ }^{140}$ Such a provision would permit greater deference to state enforcement, while insuring both that federal interests are vindicated and that the defendant is spared multiple prosecutions.

\section{Piggyback Jurisdiction from the Defendant's Perspective}

Although the primary focus of debate on piggyback jurisdiction is the conflict between state and federal authority, its impact on criminal defendants must also be examined.

\section{A. Double Jeopardy}

From the defendant's point of view, the argument that piggyback jurisdiction promotes convenience and fairness by affording a single trial for the entirety of a transaction would lose its appeal if the federal trial did not act as a bar to subsequent state prosecution for all or part of the same transaction..$^{141}$ The authors of the Code have dealt with this problem directly by including a provision that bars state prosecution in cases where a prior federal prosecution was "based on the same conduct or arose from the same criminal episode," unless the

137. 18 U.S.C. $\$ 3231$ (1970).

138. Congress gave the states jurisdiction over certain federal crimes as carly as 1794. The history of such provisions is examined in detail in Warren, Federal Criminal Lau's and the State Courts, 38 Harv. L. REv. 545 (1925). See also Testa v. Katt, 390 U.S. 386, $389-90$ (1947).

139. In Testa v. Katt, 330 U.S. 386 (1947), it was held that state courts could be not only authorized but compelled to entertain federal penal litigation. Sec Note, Utilization of State Courts to Enforce Federal Penal and Criminal Stalutes: Development in Judicial Federalism, 60 Harv. L. REv. 966 (194i).

140. For example, a simple procedure could be established whereby federal authorities could preempt state prosecution, or, as a more substantial check, state authorities could be required to obtain approval before prosecuting for federal offenses.

141. Dual state and federal prosecutions were held constitutional in Abbate v. United States, 359 U.S. 187 (1959) (federal prosecution subsequent to state prosccution) and Bartkus v. Illinois, 359 U.S. 121 (1959) (state prosecution subsequent to federal prosectition). The continuing validity of these decisions has been thrown in considerable doubt, hos:ever, by the subsequent decisions in Benton v. Maryland, 395 U.S. 784 (1969), which held the double jeopardy clause of the Fifth Amendment applicable to the states through the Fourteenth Amendment, and in Murphy v. Waterfront Comm'n, 378 U.S. 52 (19G4), which overturned the "dual sovereignty" principle as applied to the privilege against self-inerimination. 
statute underlying the previous prosecution was "intended to prevent a substantially different harm or evil" from the law defining the state offense. ${ }^{142}$ A similar provision bars subsequent federal prosecution when a state has already prosecuted, unless the Attorney General "certifies that the interests of the United States would be unduly harmed if the federal prosecution is barred."143

Piggyback jurisdiction complements this policy in two ways. First, by permitting federal prosecution for the entirety of a given transaction, it obviates the need for subsequent state prosecution. Second, it eliminates the difficulties that might otherwise arise because of the exception for subsequent state prosecution under statutes directed at a "substantially different harm or evil." If, for example, an individual impersonates a federal official in order to commit a theft, he could be prosecuted under existing federal law only for the impersonation offense, ${ }^{144}$ although he might be given a sentence close to the statutory three-year maximum because of the accompanying theft. A subsequent state prosecution for theft would probably be upheld, even under a double jeopardy provision like that proposed in the Code, on the ground that the state statute was directed at a different evil. Under the Code, however, the entire transaction could be handled at the federal

142. CoDE $\$ 708$. Such a bar to subsequent prosecution appears to be well within the constitutional authority of Congress. Although the isste will not be treated here in depth, several lines of reasoning which lead to this conclusion can be stiggested.

First, such a bar could be considered necessary to protect federal judgments in criminal cases; subsequent state trial and punishment might well frustrate the verdict or sentence decreed by the federal court. The authority of Congress to take analogous measures with respect to civil litigation appears unquestioned. See Toucey v. New York Life Ins. Co.,

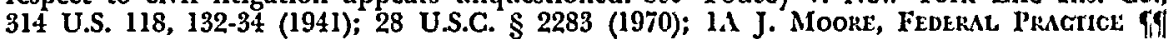
$0.208[3 .-2]-[3 .-3]$ (2d ed. 1965).

Second, it has been held that Congress can precmpt a ficld if enforcement of state crimi. nal laws is likely to interfere with a scheme of national regulation. l'cunsylvalia $v$. Nelson, 350 U.S. 497 (1956); Hines v. Davidowitz, 312 U.S. 52 (1941).

Third, it has been held that Congress has the power to remove to federal court certaln state criminal prosecutions which involve federal officers or interfere with federally-pro. tected civil rights, 28 U.S.C. $\$ \$ 1442(a), 1442 a, 1443$ (1970); Tennessec v. Davis, 100 U.S. 257 (1879), indicating that Congress can deprive the states of jurisdiction over criminal cases that affect a federal interest.

Fourth, there is a strong parallel in the well-established authority of Congress to pro. hibit state prosecution for any criminal transaction as to which a defendant has been re: quired to give testimony in a federal proceeding. Ullmann v. United States, 350 U.S. 422, 434-36 (1956); Brown v. Walker, 161 U.S. 591, 606-08 (1896).

Fifth, Katzenbach v. Morgan, 384 U.S. 641 (1966), suggests that Congress might have the authority, under $\$ 5$ of the Fourteenth Amendment, to apply a somewhat stronger staud. ard of double jeopardy to the states than is required by judicial interpretations of thic Amendment. See Cox, Constitutional Adjudication and the Promotion of Human Rights, 80 Harv. L. REv. 91, 108 (1966). But see Oregon v. Mitchell, 400 U.S. 112 (1970).

And finally, as suggested in note 141 supra, Bartkus may no longer be good authority and thus such a bar would be required by the Constitution itself, even in the absence of an act of Congress.

143. CODE $\$ 707$. That exception might be subject to constitutional challenge in the light of Benton and Murphy. See note 141 supra.

144. 18 U.S.C. $\$ 912$ (1970). 
level with a separate charge of theft piggybacked onto the impersonation offense, which carries only a one-year sentence in the Code. ${ }^{145}$ There could then be no doubt that a subsequent state prosecution for theft would be redundant-and hence prohibited.

Given the defendant's substantial interest in a single trial and the danger of inconsistent decisions by federal and state prosecutors, a subsequent state prosecution for part of a single criminal transaction should be permitted only where the defendant could not have been charged with an analogous offense at the federal trial, regardless of whether such a charge was actually brought. Thus, if the defendant in the example above were tried in federal court for impersonation but not for theft, a subsequent state prosecution for theft should be barred anyway because a piggybacked charge of theft could have been brought in the original trial. The Code already establishes such a rule as to multiple federal prosecutions. ${ }^{140}$ The language of Section 708, however, presently bars a subsequent state prosecution only in cases where the defendant was actually tried ${ }^{147}$ for the corresponding federal offense. Of course the change suggested would occasionally induce a federal prosecutor to prosecute for a piggybacked offense in a case where he might otherwise have deferred to state enforcement, and hence could run counter to the interests of federalism. In such cases, however, considerations of fairness to the defendant would seem to outweigh the rather minor incursion on state enforcement that would result.

\section{B. Consequences of Terminating the Underlying Charge}

A related issue is the disposition of a piggybacked offense when the underlying offense is terminated either by dismissal or judgment for the defendant. In such cases, the federal court should have authority to retain jurisdiction over the piggybacked offense, absent a finding that the charge for the underlying offense was clearly frivolous and was made simply for the purpose of obtaining federal jurisdiction over the underlying offense. ${ }^{148}$ Such has been the rule with respect to pendent

145. CODE $\$ 1381$. See note 93 supra.

146. CODE $\$ 703$.

147. More specifically, the double jeopardy bar applies if the defendant was convietcl or acquitted, or judgment was for the defendant on a point of fact or law that vould prevent conviction, or, with some exceptions, when the ase was terminated without the defendant's consent after the jury was impanelled. CoDE $\$ \$ 708$ and 704 .

148. The only other necessary exception to this suggested rule is for cases in which the underlying offense is dismissed for lack of jurisdiction. In that case, under the tcrms of the piggyback provision, there would be no jurisdiction over the pigg backed offense either, which would then also have to be dismissed for lack of jurisdiction. Fen. R. Cris. P. 12(b)(2). Such a dismissal is not a bar to subsequent statc prosecution. Code $\$ 709$. 
jurisdiction in civil litigation, ${ }^{140}$ and there is no reason for a different result with respect to piggybacking.

The reasons for adopting this approach, rather than the alternative of requiring dismissal of the piggybacked offense whenever the underlying charge is terminated, are the same considerations of convenience and fairness that support piggyback jurisdiction itself. ${ }^{150}$ At least when a case has advanced well beyond the pleadings, a dismissal of the piggy. backed charges and a subsequent retrial in state court would be likely to involve substantial delay and duplication of effort. In such situations, the judge should exercise his discretion as to the dismissal of the piggybacked offense, with due regard for the interests of each of the parties involved. In particular, he should consider the stage at which the underlying offense is dismissed, whether the state statute covering the piggybacked offense is significantly different from the federal statute, and the original reason for federal prosecution. ${ }^{151}$

\section{Plea Bargaining}

The increased flexibility that piggyback jurisdiction would give federal prosecutors in framing indictments would increase significantly the opportunities for plea bargaining. As a result, the familiar questions concerning the fairness of that practice would become all the more acute. ${ }^{152}$

However severe the objections to plea bargaining, they do not warrant rejection of piggyback jurisdiction. Even from the defendant's perspective, there would be little to gain from such a response. Any other equally flexible system of defining aggravating offenses would also provide substantial room for bargaining. On the other hand, a less flexible system, such as the present one, would in some cases provide for arbitrarily high sentences and in others, where the federal penalty seemed

149. United Mine Workers of America v. Gibbs, 383 U.S. 715 (1966); A.H. Emery Co. v. Marcan Products Corp., 389 F.2d 11 (2d Cir. 1968).

150. See pp. 1220-21 supra.

151. For example, if the trial has already progressed to an advanced stage, the fcderal statute covering the piggybacked offense is nearly identical to the state statute in defini. tion, defenses, and penalty, and the reason for federal prosecution was a breakdown in local law enforcement due to corruption, there would seem to be no reason to relinquish jurisdiction.

It is assumed here that the defendant has consented to or requested the dismissal of the piggybacked offense. The government, of course, has the authority to dismiss stich a charge whenever it wishes to do so, though if the trial has begun and the defendant's consent is not obtained, the dismissal should act as a bar to a subscquent trial for the piggybacked offense under the same circumstances as provided in the Code for the dis. missal of any other federal offense. See CoDE $\$ \$ 704(d), 705(a), 707(a), 708(a)$.

152. See generally Note, The Unconstitutionality of Plea Bargaining, 83 HAkv. L. REv. 1387 (1970); 'The President's Commission on Law Enforcement and Administration of JUSTICE, TASK ForCe Rerort: The Courts 9.14 (1967). 
too low, would probably result in transferring the defendant to state authorities for prosecution of all or part of the crime. In the latter case the defendant would be faced with plea bargaining in the state courts, not to mention the possibility of dual state and federal prosecution. ${ }^{153}$ The enactment of the new Code would, nevertheless, be an appropriate occasion for considering some of the current proposals for plea bargaining reform. ${ }^{154}$

\section{Cumulative Sentencing}

The increased variety of charges that piggybacking makes available also increases the possibility that an individual might be convicted and given cumulative sentences for a number of offenses based on the same conduct, so that the punishment administered in certain cases could be unduly harsh. The Code deals with this problem directly through a provision specifically limiting the situations in which cumulative sentences may be imposed. Section 3204 provides that consecutive sentences may not be imposed where one offense is included in another or consists only of preparation for or facilitation of the other (such as conspiracy or attempt), or where one offense simply prohibits a specific instance of conduct prohibited generally by the other. Furthermore, the total sentence that may be imposed is generally limited to the maximum penalty carried by the most serious offense involved, with an exception as to sentencing for two or more offenses of roughly equal seriousness where each "was committed as part of a different course of conduct, or each involved a substantially different criminal objective." 155 These provisions are clearly valuable additions to the existing law.

\section{E. Precision in Drafting}

A final consideration is the specificity of the charges with which a defendant is faced. Previous efforts at adjusting penalties for federal offenses according to the severity of aggravating incidents have been vague and imprecise. The fairly common provisions increasing the maximum penalty under various statutes to life imprisonment "if

153. Plea bargaining, of course, might also be seen as advantage by a large number of defendants who would prefer to have the opportunity to plead guilty to a lesser offense.

154. See, e.g., American Bar Association Project on Minimum Standaros for Criminal. Justice, Standards Reitinic to Pleas of Guizty (Tent. Draft 1967), adopted as amended, 2 Crim. L. Rep. 2422 (1968); The President's Conmmssion on Laiv Enforcesient and AdMinistration of Justice, TASK Force Report: The Courts 12 (1967).

155. CODE $\$ 320 \leq(3)$. 
death results,"156 for example, do not differentiate among degrees of culpability; the punishment is the same whether the death is negligently caused or viciously planned. Even the somewhat more carefully drafted bank robbery statute ${ }^{157}$ rather arbitrarily establishes an additional sentence of up to twenty-five years for any associated assault, regardless of its nature, and provides for life imprisonment when the offender "kills" someone, again without respect to the degree of culpability. The replacement of such provisions by the piggybacking of carefully defined offenses would assure defendants that the government will have to charge and prove separately each item of conduct that aggravates the punishment, and that the resulting sentence will be at least roughly proportional to the seriousness of the conduct involved.

\section{Conclusion: The Alternatives to Piggybacking}

There are at least three broad alternatives to piggyback jurisdiction. Each would fulfill essentially the same function, though each is in certain respects inferior to piggybacking.

First, piggybacking could be replaced by more conventional techniques for dealing with compound offenses. The most obvious ap. proach would be to provide increased penalties for individual offenses when associated with various forms of aggravating conduct. For example, the crime of robbery could be defined so as to be punishable by more severe sentences when accompanied by aggravated assault or murder, as in the present bank robbery statute. Reference could be made, in turn, to a separate set of definitions for such common forms of aggravating conduct as assault, murder, and theft, thus eliminating inconsistencies of definition and assuring that all the requisite elements of the conduct, including the appropriate degree of culpability, would be clearly set forth.

Such an approach would not necessarily frustrate the other major jurisdictional innovation in the Code-the separation of jurisdictional bases from definitions of criminal conduct-and it would permit a more selective approach to the extension of federal jurisdiction over incidental offenses. ${ }^{158}$ On the other hand, the resulting definitions of

156. See p. 1214 supra.

157. See p. 1214 supra.

158. Note that a combination of this approach and the piggyback proposal is also possible; in place of CODE $\$ 201(\mathrm{~b})$, the jurisdictional provision for any given offense in chapters 16 or 17 could contain a statement that there is jurisdiction over that offense whenever it is committed "in the course of committing" any of a set of crimes which is explicitly listed. Thus, different offenses could be given piggyback jurisdiction of different scope. 
offenses might be exceedingly cumbersome, ${ }^{159}$ and, no matter how carefully drafted, they would almost certainly be unable to avoid situations, characteristic of the present law, in which various incidents within a given transaction are not appropriately covered by the definitions. Furthermore, such an approach would leave open the possibility of inconsistent or less carefully drafted future additions and hence of the re-emergence of the haphazard pattern that characterizes the present law. 160

As a second alternative, it has been suggested that the practice of assigning a series of particular jurisdictional bases to individual offenses, followed in both the Code and the existing law, might be eliminated in favor of a single provision making all crimes federally cognizable when committed "within the federal jurisdiction," a phrase that could be defined to comprehend every desired basis for federal jurisdiction. ${ }^{161}$ Although this approach would obviate the need for special devices for aggravating offenses, it would not eliminate the problem of defining the unit of behavior-that is, the scope of the transaction-to which federal jurisdiction would attach.102 Furthermore, such an approach could involve a substantial expansion of federal authority, and consequently pose a far greater threat to the values of federalism than does piggybacking. ${ }^{103}$

159. Presumably the definition of each offense would have to include a reference to every possible aggravating offense. In some cases, for example where the offense is impersonation of a federal officer, this might extend to nearly every offense now contained in chapters 16 and 17 of the Code. Providing for an appropriate sentence in such definitions could be an especially difficult problem. Thus, if impersonation could be agstasated by the act of theft, there would have to be some provision for adjusting the sentence according to the character of the theft-a problem that requires almost two full pages in CODE $\$$ 1735, the provision that covers grading of theft offenses in chapter 17. Ot course, such sentencing provisions could be stated separately and incorporated by reference. Yet the more such devices are employed, the closer this approach resembles the piggiback technique.

160. See p. 1211 supra.

161. Schwartz, supra note 18. Professor Schwartz offered the following definition for the phrase as a subject of discussion for the Commission:

Federal jurisdiction exists if -

(i) Federal facilities were employed at any stage of the offense;

(ii) the Federal government or any of its agencies, property, personnel, functions,

or interests was harmed or imperiled by the behavior;

(iii) the offense occurred in Federal territory;

(iv) the offense occurred on a vessel ....;

(v) the offense infringed upon a federal statutory or constitutional right;

(vi) by reason of any other circumstance in the case Federal prosecution would be constitutionally permissible.

Abrams, Consultant's Report on Jurisdiction, 1 WORkING PAIERs 33, 50.

162. In the jurisdictional provision quoted in note 161 supra, for example, there would still be a need to define such words as "offense," "behavior," and "case."

169. The breadth of the resulting jurisdiction would of course depend on the particu. lar definition used. If clause (vi) of the definition in note 161 supra were omitced, for example, the result would be muct, the same as if the Code were simply altered to pro. vide for jurisdiction over all offenses under every jurisdictional base set forth in section 201. 
A third alternative would be to provide for "true" pendent criminal jurisdiction-that is, to permit prosecution of state offenses in federal court whenever they are included within the same transaction as a federal offense. ${ }^{164}$ This approach would permit a great deal of flexibility in framing an indictment, while at the same time respecting the right of each state to write its own criminal law. Yet it has the obvious disadvantage of requiring the application of two or more systems of criminal law to a single transaction. ${ }^{185}$

The proposal for piggyback jurisdiction essentially captures the best of each of these alternatives. It permits continuation of the particularistic treatment of jurisdictional bases and aggravating offenses, pro. vides for the application of a single body of federal law to the entirety of a criminal transaction, limits federal jurisdiction to only those offenders already subject to federal prosecution, and assures sufficient authority and flexibility to prosecute all the offenses involved in a given transaction.

164. The result would still differ from the form of pendent jurisdiction employed in civil litigation in that it could provide for appending an additional party-the statewithout first obtaining that party's consent, and without letting that party represent itself. Even this result is not unprecedented, however. The pendent jurisdiction rulc of Gibls, pp. 1220-21 supra, has been held to extend to pendent parties, see Astor-Honor, Inc. v. Grosset \& Dunlap, Inc., 441 F.2d 627 (2d Cir. 1971), and under Fed. R. Civ. P. 24 (Inter. vention) an individual does not always have the right to represent his own interests in an action in federal court.

165. See p. 1222 supra. 